\title{
The Structure of Matter in the Unit of 4E Model and Its I mpact on Science Process Skills
}

\author{
Sevilay KARAMUSTAFAOĞLU*
}

\author{
Bahri MEŞECI ${ }^{* *}$
}

Accepted: 17 March 2014

\begin{abstract}
This research with four-stage model is enriched with activities supported by the scientific process skills of teachers to develop guidance material and this material is carried out to determine the effectiveness of the process of teaching science process skills. For this purpose, scientific process skills test developed by Enger and Yager and applied on 48 students. Iteman program and 5 item with low reliability are removed. The final status is 31 items. The test result of the analysis of the collected data indicated that the test scores of students' science process skills are significantly different and they were in favour of the experimental group. Primary education is the first stage of the education and this sort of research is extremely good for teacher candidates. By the help of this research, teacher candidates can receive a very good science education.
\end{abstract}

Keywords: particulate structure of matter, process skills in science, change of substance

\section{Extended Abstract}

Purpose and Significance: The aim of this research is to prepare a material for secondary class $6^{\text {th }}$ grade students for the unit 'particulate structure of matter'. This developed material is used to investigate the effectiveness of science process skills.

The unit of structure of matter is developed and it meets the lack of the information needed by teachers. This developed material helps to improve the renovation program of the secondary school and it will contribute to solve the problems faced by the teachers during teaching sessions. This material can evaluate the students' learning process and it should be placed in the curriculum. It is used to analyse the students' learning processes. This context is based on the philosophy of the new program based on overlapping approaches to teaching learning theories and assessment will be useful for educators who want to improve the quality of education in this study.

Methods: In this study, a quasi-experimental method is used. This method provides a test of a control group but the groups are not determined randomly. If there is a significant difference between pre-test scores of the groups, it can be mentioned equivalence of groups. Tropics of both groups indicate the changes in the points compared to the last test and it can be seen that if there is a significant difference. Semiempirical method of random groups is determined to carry out the research. Most of the research is carried out in the schools and a random selection of the sample is very

\footnotetext{
* Corresponding Author: Assoc. Prof. Dr., Amasya University, Faculty of Education, Amasya, sevilayt2000@yahoo.com

*** Teacher, Amasya.
} 
difficult. Researchers often are not allowed by the administrative units of the schools to carry out the research. So they generally use a quasi-experimental method. study used quasi-experimental methods.

Results: Before the experiment and control group applications, it is known that there is a significant difference between the levels of science and process skills. After the application, the experimental and the control groups are formed. However, both techniques were used to develop a significant difference in the level of students' science process skills.

4E-step approach in learning science process skills includes a wide range of activities developed by the researcher . Science books published for $6^{\text {th }}$ grade by the Ministry of Education do not contain enough science process skills which is used in classrooms . 6th grade text books published by the Ministry of Science and Technology only examine the basic process skills such as communication skills.

Investigating the effectiveness of countries' programs is evaluated by international exams. These exams can measure the ability of the students' thinking and using the skills in the real life. According to the analysis of 38 countries participated in TIMSS1999, this study is calculated on the average of the participating countries of 488 international average. Turkey is at the lower rank of the international level. International activities in the books of the examinations show that the Ministry of Education does not contain enough content.

Discussion and Conclusions: Pre-test scores of the experimental group and the control group do not indicate any difference about science process skills of the students.

The results of post-test scores indicate that there is a significant difference in favour of the experimental group students' science process skills. 4E-step learning approach is developed by the researcher during the research phase. The material used for the experimental group indicates that students have learned to use the scientific process skill. The following recommendations have been suggested as a result of the research.

- The elementary school is the first step to learn scientific issues. If one wants to give a good education to his students, a candidate teacher has to improve himself in the university and they have to study science in the faculty of education.

- Training programs can be improved by the teachers and if it is examined in detail, in-service courses should be opened.

- Activities are prepared according to students' level and their scientific process skills.

- Enrichment activities should be prepared to develop students' level and their scientific process skills. 


\title{
Maddenin Tanecikli Yapısı Ünitesine Yönelik 4E Modeli Destekli Etkinliklerin Bilimsel Süreç Becerilerine Etkisi
}

\author{
Sevilay KARAMUSTAFAOĞLU*
}

\author{
Behri MEȘECI ${ }^{* *}$
}

Makale Gönderme Tarihi: 24 Aralık 2013

Makale Kabul Tarihi: 17 Mart 2014

\begin{abstract}
ÖZET: Bu araştırma, ortaokul 6. sınıf 'Maddenin Tanecikli Yapısı' ünitesine yönelik bilimsel süreç becerileri etkinlikleriyle zenginleştirilmiş dört aşamalı model destekli öğretmen rehber materyali geliştirmek ve bu materyalin öğretim sürecindeki bilimsel süreç becerileri açısından etkililiğini belirlemek amacıyla yapılmıştır. Bu amaç doğrultusunda Enger ve Yager (1998) tarafından geliştirilen bilimsel süreç becerisi testi 300 öğrenciye uygulanmıştır. ITEMAN programı ile güvenirliği düşük olan 5 madde çıkarıldıktan sonra, teste 31 maddelik son hali verilmiştir. KR-21 güvenirlik katsayısı. 81 olarak tespit edilmiştir. $\mathrm{Bu}$ çalışma yarı deneysel yöntem kullanılarak gerçekleştirilmiştir. Araştırmanın çalışma grubu Amasya ili Merkez ilçesinde belirlenen bir okulda 25 deney, 23 kontrol grubu öğrencilerinden oluşmaktadır. Uygulamalardan elde elden verilerin analizi sonucu, deneysel çalışma sonrasında araştırmaya katılan deney ve kontrol gruplarındaki öğrencilerin bilimsel süreç becerileri puanları arasında istatistiksel olarak deney grubu lehine anlamlı farklılık bulunmaktadır. İlgili araştırma 6. Sınıf 'Maddenin Tanecikli Yapısı' ünitesi ile gerçekleştirilmiştir. Bilimsel süreç becerilerinin daha etkili bir şekilde kazandırılması için ilgili materyalde olduğu gibi etkinlikler diğer öğrenim düzeyleri ve konular için de geliştirilebilir. Böylelikle hem bilimsel süreç becerilerinin gelişiminin takibi yapılabilir, hem de öğrencilerin akademik başarıları arasındaki farklılıklar tespit edilebilir.
\end{abstract}

Anahtar sözcükler: bilimsel süreç becerileri, maddenin tanecikli yapısı, maddenin değişimi

\section{Giriş}

Dünya'da ve ülkemizde fen bilimleri ve eğitiminin insan yaşamında önemli bir yeri vardır. Bilimsel bilgilerin geliştirildiği, teknolojik çalışmaların yapıldığı, fen ve teknolojinin izlerinin etkili bir şekilde hissedildiği günümüzde fen bilimleri anahtar bir rol oynamaktadır. Toplumların gelişmişlik düzeyleri incelendiğinde ön sıralarda yer alan ülkelerin fen eğitimine daha fazla önem verdikleri dikkati çekmektedir. Bu bağlamda, fen bilimleri eğitimi üzerinde durulması gereken bir konudur. Fen eğitiminin bu önemli gelişmelere sebep olduğu düşünüldüğünde etkili ve kalıcı olması için ayrı bir önem verilmesi gerektiği anlaşılır.

Fen öğretiminin etkili olabilmesi durumunda, öğrencilerin düşünme becerileri gelişir, düşünmenin kökenini var eden kavramsal temellerin anlaşılması kolaylaşır, özgüveni sağlar ve problemlere yönelik olarak çözüm yollarını keşfedebilme becerisi gelişir (Başar, 1992). Bunların yanında, fen bilimleri eğitimi, hipotez kurma, test etme, gözlem yapma, veri toplama, verileri yorumlama, çıarımda bulunma gibi becerilerin gelişmesi konusunda öğrencilere yardımcı olur. Hayal kurma, yaratıcılık, yeni fikirlere açık olma, zihinsel dürüstlük ve sorgulama becerisi kazandırır. Bunlarla birlikte, öğrenciyi yaşama hazırlayabilme, günlük yaşam ve bilgi arasındaki ilişkiyi anlayarak, bilimsel bilgiyi keşfetme ve bilginin kalıcılığına katkı sağlama gibi beceriler de kazandırmaktadır.

Fen bilimleri eğitimi ile bilgiye nasıl ulaşabileceklerini öğrenen bireyler bu bilgileri ihtiyaçlarını gidermeye yönelik beceri haline getirirler. Bu beceri planlı olarak ilk defa ilkokul yıllarında karşılarına çıkar (Kaptan ve Korkmaz, 2000). Bu beceriler o

\footnotetext{
* Sorumlu Yazar: Doç. Dr., Amasya Üniversitesi, Eğitim Fakültesi, Amasya, sevilayt2000@yahoo.com

*** Öğretmen, Milli Eğitim Müdürlüğü, Amasya.
} 
yıllarda kazandırılması gereken kazanımlar veya göstergeler olarak öğretim programlarında yer alır. Bu becerilerin daha etkili olabilmesi ve planlanan hedeflerin gerçekleşebilmesi için, yöntemlerin doğru seçilmesi ve uygulanması gerekmektedir ( Ayas, Çepni ve Akdeniz, 1993). Bu nedenle fen öğretimi düşünme becerilerini geliştiren, problem çözme becerisini güçlendiren ve bireyin geleceğine yol gösteren önemli bir role sahiptir.

Fen eğitimin etkili bir şekilde gerçekleştirebilmek öğrencilerin sözel yollardan ziyade, birinci elden deneyimlerle karşılaştırılması gerekmektedir. Burada öğrencinin birinci elden deneyimle karşılaşması, bilimsel süreç becerileriyle mümkündür. Bilimsel süreç becerileri bir bütün olarak düşünüldüğünde, bu bütünü günlük hayatın içindeki parçaların oluşturduğu söylenebilir (Turgut, 1997).

Bilindiği gibi bilim insanları gözlem ve sınıflandırma yapan, ölçen, sonuç çıkaran ve deneyler yapan kişilerdir. Bilimsel süreç becerileri bilim insanlarının en çok kullandıkları becerilerdir. $\mathrm{Bu}$ becerilerin temellerinin atılması ilkokul yıllarında gerçekleştirilebilir. Ancak buradan herkesin bilim insanı olacağı sonucuna varılmamalıdır. Bilimi anlamanın yolu, bilim insanı gibi bakmaya ve uğraşmaya bağlıdır (Ostlund, 1992). Bilimsel süreç becerileri, bilimin safhalarını oluşturan bilişsel ve araştırma becerisi ile ilgilidir (Goh, Toh ve Chia,1989 aktaran: Arena, 1996).

Fen öğretiminde bilimsel araştırma yöntemleri kullanılırken bazı noktalara dikkat edilmelidir. Bilimsel süreç becerileri öğrencilere yönelik etkinlik çalışmaları ile gelişecektir. Bu becerilerin geliştirilmesinde öğrencilerin yaşı göz önüne alınmalıdır. İlk kademe temel süreç becerilerine yönelik etkinlikler sunulmalıdır. Bu etkinliklerle ögrencilerin detaylı gözlem yapma, ölçüm yapma, yapılanların ve verilerin kaydedilmesi, verileri yorumlama, verilere dayanarak çıkarımlar yapma gibi becerilerin geliştirilmesi amaçlanması gerekmektedir. Bu tür beceriler daha üst becerilerin temelini hazırladığı için bu şekilde adlandırılmıştır (Martin, Sexton ve Gerlovich, 2002). Temel süreç becerileri aşağıdaki gibi ifade edilebilir.

Sınıflama Yapma: Gözlem yoluyla toplanan verilerin düzenlenmesidir. Nesne ya da olayları özelliklerinin benzerlik ya da farklılıklarına göre gruplandırma ya da düzenleme olarak da ifade edilebilir.

Ölçme: Yapılan gözlem sonucu ölçümün sayısal veriler ile ifadesidir. Ölçme işlemi yapılırken standart olan ve olmayan aletlerle yapılır. Bazen adım ile sınıfı adımlarken, bazen ise metre kullanılarak sınıfın uzunluğu ölçülebilmektedir. Ölçümler sabit kalan değerler olarak da görülmemelidir. Bir fidanın boyu ölçümü zaman içerisinde fidanın büyümesine bağlı olarak değişebilir. Değişimi belirlemek için ölçme işleminin tekrar tekrar yapılması gerekmektedir. Ölçümlerin tekrarlanması da ölçme sonuçlarına karışacak hata payının en aza indirilmesini sağlamaktadır.

Çıkarım Yapma: Gözlemlerin nedenleri konusunda yapılan tahminler olarak tanımlanır. Çıkarımların yapılabilmesi için elimizde verilerin olması gerekmektedir.

Tahminde Bulunma: Gözlemler sonucu, elimizdeki veriler ile gelecekteki bir durumun ve bu durumun sonuçlarını kestirme becerisi olarak tanımlanır.

Çıkarımlar, geçmişte yaşanmış olayların muhtemel açıklaması olarak ifade edilirken tahminler, gelecekte yaşanması muhtemel durumlarladır.

İletişim Kurma: Veriler sonucu elde edilen bilgilerin insanlar ile paylaşımının sağlanması için çeşitli formlara dönüştürülen mesaj olarak adlandırılmaktadır. Resimler, grafikler, şekiller, şemalar, diyagramlar bu formlara dönüştürülmüş mesajlara örnek olarak verilebilir. 
İlkokul kademesindeki öğrencilerin temel becerileri gelişmişse, diğer kademelerde daha üst düzey becerileri içeren bilimsel araştırmalar yapılabilir ve fen öğretiminde araştırmalara daha çok yer verilebilir. Bu şekildeki öğretimde öğrencilerin düşünme biçimlerinin gelişmesine katkı sağlanmış olur. İkinci kademedeki öğrencilerin kazanması gereken bütünleştirilmiş beceriler aşağıda sunulmaktadır. Temel becerilerden birçoğunun ilişsili olarak düzenlenmesi ve inşa edilmesinden kaynaklı olarak bu beceriler birleştirilmiş beceriler olarak da ifade edilmektedir (Martin, Sexton ve Gerlovich, 2002).

Operasyonel (İşlevsel) Tanımlama: Öğrencilerin kavramların formal tanımlarını ezberlemek yerine, kendi tecrübe ve gözlemlerinden elde ettikleri bilgiler doğrultusunda, kendi tanımlarını oluşturmalarıdır.

Hipotez Kurma: Doğruluğu araştırma ve deneyler sonucu test edilmeye çalışılan öngörülere denir. Deney ile sinanabilecek kanıtlara dayalı tahminler yapma olarak tanımlanabilir. Hipotez kontrollü ve formal olarak yapılmaktadır.

Verileri Yorumlama: Hipotezler doğrultusunda toplanan verilerin bilgisayar ve hesap makinesi gibi araçlarla görsel formlara (grafik, tablo) dönüştürülmesi verileri yorumlamayı kolaylaştırır

Deney Yapma: Öğrencilerin bütün bilimsel süreç becerilerini uygulamalarını gerektiren deney tasarlama ve yapma, araştırma sürecinin en geniş bölümünü oluşturur.

İlgili literatürde, bilimsel süreç becerilerinin öğretimindeki rolü, günlük yaşamda ortaya çıkan problemleri araştırmaya ve çözmeye kolaylık sağlayan beceriler olarak ifade edilmektedir (Aktamış, 2009). Bilimsel süreç becerilerinin farklı şekillerde tanımlandığı görülmektedir; Şahin-Pekmez (2000), “ bilimsel süreç becerilerini, ögrenmeye yardım eden, keşfetme yöntemlerini ögreten, ögrencileri aktif yapan, onların sorumluluklarını geliştiren ve laboratuvar çalışmalarını anlamalarına yardımcı olan temel beceriler " olarak tanımlamaktadır. Taşar ve arkadaşları (2001) bilimsel süreç becerilerini fen bilimlerinde öğrenmeyi daha etkili kılan, araştırma becerilerini kazandıran, öğrencilerin etkinliğini artıran, öğrenmede sorumluluk alma duygusunu geliştiren ve öğrenmenin etkinliğini artıran temel beceriler olarak belirtmektedir. Temel becerilerin ilkokul düzeyinde, üst düzey becerilerin ise ortaokul düzeyinde daha etkili olarak kazandırılabileceği ifade edilmektedir ((Büyüktaşkapu, Çeliköz ve Akman, 2012). Bu öğrenim düzeylerinde ilgili becerilerin kazandırılması önemlidir. Bilimsel süreç becerileri sadece aşama aşama izlenmesi gereken basamaklar olarak görülmeme ve aynı zamanda düşünce biçimini oluşturan beceriler bütünü olarak değerlendirilmelidir (Ergin, Şahin-Pekmez ve Öngel-Erdal, 2005). Bu becerilerin kazandırılması ilkokul ve ortaokul düzeyinde öğretim yapan fen öğretmenlerinin önemli bir problemidir (Çetin ve Günay, 2011; Karamustafaoğlu ve Kandaz, 2006). Uluslararası düzeyde yapılan sınavlarda ülkemizdeki öğrencilerin bilimsel süreç becerilerinin eksiklikleri tespit edilmiştir (Anagün, 2011; Sarıer, 2010; Karamustafaoğlu ve Sontay, 2012). İlgili bu çalışmayla özellikle öğretmenlerin bu konudaki bilgi eksikliklerine ve uygulamada yaşadıkları problemlere katkıda bulunacağı, yenilenen ortaokul programında sıklıkla kullanılması gereken bu tür materyallerin öğretmenlerin ders sürecinde ve uygulamalarında yardımcı olacağı düşünülmektedir. 2004-2005 İlköğretim programında yer alan süreci de değerlendirme imkanı tanıyan alternatif değerlendirme yaklaşımları, bu çalışmada kullanılmıştır. Bu bağlamda yeni programın dayandığı felsefe, esas aldığı öğrenme-öğretme teorileri ve ölçme değerlendirme yaklaşımlarıyla örtüşen bu çalışmanın, öğretimin niteliğini artırmak isteyen eğitimcilere faydalı olacağı düşünülmektedir. 
Ortaokul düzeyinde ünite bazında fen öğretmenlerine yönelik bilimsel süreç becerilerinin kazandırılmasında rehber olacak bir materyalin geliştirilmesi ve etkililiğin belirlenmesi bu çalışmanın problemini oluşturmaktadır.

\section{Problem Cümlesi}

Ortaokul 6. sınıf 'Maddenin Tanecikli Yapısı' ünitesine yönelik bilimsel süreç becerileri etkinlikleriyle zenginleştirilmiş 4E model destekli öğretmen rehber materyalinin öğretim sürecinde öğrencilerin bilimsel süreç becerilerine etkisi var mıdır?

\section{Alt Problemler.}

1. Deney ve kontrol gruplarının Bilimsel Süreç Becerileri ön-test puanları arasında anlamlı düzeyde bir farklılık var mıdır?

2. Deney ve kontrol gruplarının Bilimsel Süreç Becerileri son-test puanları arasında anlamlı düzeyde bir farklılık var mıdır?

\section{Yöntem}

Bu çalışmada, 6. sınıf 'Maddenin Tanecikli Yapısı' ünitesine yönelik bilimsel süreç becerileri etkinlikleriyle zenginleştirilmiş dört aşamalı model destekli öğretmen rehber materyali geliştirmek ve bu materyalin öğretim sürecindeki bilimsel süreç becerileri açısından etkililiğinin araştırılması amacıyla yarı deneysel yöntem kullanılmıştır. Yarı deneysel yöntem; değişkenler arasında neden-sonuç ilişkilerini keşfetmek amacıyla kullanılan bir desendir (Büyüköztürk,2001). Bazı durumlarda kişilerin gruplara rasgele dağıtılması imkânsız olabilir veya istenmeyebilir. Bu durumlarda alternatif olarak yarı deneysel yöntem kullanılır. Bu yöntem; kişilerin deney ve kontrol gruplarına gönderilmesinde rasgele dağılımın kullanılmadığı bir deney yaklaşımını içeren tasarımdır. Başka bir deyişle yarı deneysel yöntem, bağımsız değişkenin, bağımlı değişken üzerindeki etkisinin karşılaştırılarak karara varılmasını sağlayan bir araştırmadır. Araştırma; bilimsel süreç becerileri testinden elde edilen veriler üzerinden yürütülmüştür. Araştırma, 6. sınıflarda Fen ve Teknoloji dersi “ Maddenin Tanecikli Yapısı” ünitesinde yapılmıştır.

\section{Araştırmanın Örneklemi}

Bu çalışma Amasya ili Merkez İlçesindeki bir Ortaokulunda yapılmıştır. Deney grubu 25 öğrenciden, kontrol grubu ise 23 öğrenciden oluşmaktadır. Bu okuldaki 6. sınıf öğrencileri araştırmanın örneklemini oluşturmaktadır.

Tablo 1

Örneklem Demografik Bilgileri

\begin{tabular}{ccccc}
\hline & \multicolumn{2}{c}{ Deney Grubu } & \multicolumn{2}{c}{ Kontrol Grubu } \\
\hline Cinsiyet & K1z & Erkek & K1z & Erkek \\
\hline$(f)$ & 11 & 14 & 10 & 13 \\
\hline
\end{tabular}


Tablo 1'de görüldüğü gibi deney grubu 11'i kı, 14'ü erkek olmak üzere 25 öğrenciden oluşurken, kontrol grubu ise 10'u k1z, 13'ü erkek 23 öğrenciden oluşmaktadır.

\section{Veri Toplama Araçları}

Araştırmada veri toplama araçları olarak bilimsel süreç beceri testi kullanılmıştır. Bu bölümde araştırma verilerini toplamak için kullanılan araçlardan söz edilecektir.

\section{Bilimsel Süreç Becerileri Testi (BSBT)}

Enger ve Yager (1998) tarafindan geliştirilen bilimsel süreç becerisi testi, Birinci (2008) tarafından Türkçe'ye çevrilmiş ve güvenirlik çalışması için öncelikle benzer özelliklere sahip 300 öğrenciye uygulanmıştır. ITEMAN programı ile güvenirliği düşük olan 5 madde çıkarıldıktan sonra, teste 31 maddelik son hali verilmiştir. $\mathrm{Kr}-21$ güvenirlik katsayısı .81 olarak tespit edilmiştir. Testin bilimsel süreç becerilerine göre soru dağglımı Tablo 2'de gösterilmiştir.

Tablo 2

Becerilere Göre Soru Dă̆llım Çizelgesi

\begin{tabular}{cccc}
\hline Temel Süreç Becerileri & Soru Sayısı & Bütünleştirici Süreç Becerileri & Soru Sayısı \\
\hline Gözlem yapma & 2 & Değişkenleri kontrol etme & 3 \\
Uzay/zaman ilişkisi & 3 & Verileri yorumlama & 2 \\
Sınıflandırma & 3 & Hipotez oluşturma & 3 \\
Sayıları kullanma & 3 & Tanımlama & 1 \\
Ölçüm yapma & 3 & Deney yapma & 2 \\
İlişkilendirme & 3 & Tahmin yürütme & 3 \\
\hline
\end{tabular}

Tablo 2 'de görüldüğü gibi bilimsel süreç becerileri testi, temel süreç becerileri ve bütünleştirilmiş süreç becerileri olmak üzere sınıflandırılmıştır. Her beceriyi kapsayacak sorular sorulmuştur. Temel süreç becerilerinden 17 soru sorulurken, bütünleştirici süreç becerilerinden 14 soru sorulmuştur.

Testin kapsam geçerliği için uzman görüşleri alınmış ve KR-21 güvenirlik katsayısı .81 olarak tespit edilmiştir.

\section{Verilerin Analizi}

Çalışmanın verileri, bilimsel süreç becerileri testi ile elde edilmiştir. Ön-test ve son-testlerin uygulanması ile elde edilen veriler bilgisayar ortamına aktarılarak SPSS programı yardımıyla analiz edilmiştir. Deney ve kontrol gruplarının ön ve son-test testlerinin bulgularını analiz etmek amacıyla bağımlı ve bağımsız gruplar için t-testi 
analizleri yapılmış; veriler, tablolar ve grafikler ile sunulmuştur. Verilerin normal dağılıma uyduğu ve varyansların homojen olduğu varsayılmıştır.

\section{Bulgular}

$\mathrm{Bu}$ bölümde, kullanılan yarı deneysel yöntem sonunda her bir alt probleme yönelik yapılan istatistikî işlemlerle elde edilen bulgular sunulmuştur.

\section{Birinci Alt Probleme İlişkin Bulgular}

Bilimsel Süreç Becerileri Testi uygulandığında, deney ve kontrol gruplarının öntest puanları arasında anlamlı düzeyde bir farklılık var mıdır? şeklinde olup, ilgili testin ön-test olarak uygulanmasından elde edilen deney ve kontrol grubu öğrencilerinin doğru cevap yüzdeleri Tablo 3'de sunulmuştur.

Tablo 3

BSBT Ön testine Kontrol ve Deney Grubu Öğrencilerinin Doğru Cevap Verme Yüzdeleri 


\begin{tabular}{|c|c|c|c|c|c|c|c|c|c|c|}
\hline & \multirow[t]{4}{*}{ Beceriler } & \multirow{3}{*}{$\begin{array}{l}\text { Madde } \\
\text { Numarası }\end{array}$} & \multicolumn{4}{|c|}{ Deney Grubu } & \multicolumn{4}{|c|}{ Kontrol Grubu } \\
\hline & & & \multicolumn{2}{|c|}{ Doğru } & \multicolumn{2}{|c|}{ Yanlış } & \multicolumn{2}{|c|}{ Doğru } & \multicolumn{2}{|c|}{ Yanlış } \\
\hline & & & $f$ & $\%$ & $f$ & $\%$ & $f$ & $\%$ & $f$ & $\%$ \\
\hline & & 1 & 0 & 0 & 25 & 100 & 1 & 4.3 & 22 & 95.7 \\
\hline & \multirow[t]{3}{*}{ Gözlem Yapma } & 2 & 25 & 100 & 0 & 0 & 21 & 91.3 & 2 & 8.7 \\
\hline & & 3 & 9 & 36 & 16 & 64 & 6 & 26.1 & 17 & 73.9 \\
\hline & & 4 & 20 & 80 & 5 & 20 & 11 & 47.8 & 12 & 52.2 \\
\hline & \multirow[t]{3}{*}{ Uzay Zaman İlişkisi } & 5 & 13 & 52 & 12 & 48 & 17 & 73.9 & 6 & 26.1 \\
\hline & & 6 & 16 & 64 & 9 & 36 & 11 & 47.8 & 12 & 52.2 \\
\hline & & 7 & 16 & 64 & 9 & 36 & 16 & 69.6 & 7 & 30.4 \\
\hline & \multirow[t]{3}{*}{ Sinıflandirma } & 8 & 23 & 92 & 2 & 8 & 21 & 91.3 & 2 & 8.7 \\
\hline & & 9 & 24 & 96 & 1 & 4 & 20 & 87 & 3 & 13 \\
\hline & & 10 & 25 & 100 & 0 & 0 & 22 & 95.7 & 1 & 4.3 \\
\hline & \multirow{2}{*}{ Sayıları Kullanılma } & 11 & 24 & 96 & 1 & 4 & 18 & 78.3 & 5 & 21.7 \\
\hline \multirow{10}{*}{ 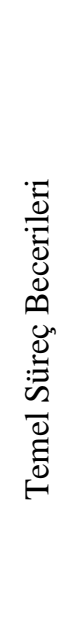 } & & 12 & 18 & 72 & 7 & 28 & 13 & 56.5 & 10 & 43.5 \\
\hline & \multirow[t]{4}{*}{ Ölçüm Yapma } & 13 & 11 & 44 & 14 & 56 & 6 & 26.1 & 17 & 73.9 \\
\hline & & 14 & 15 & 60 & 10 & 40 & 13 & 56.5 & 10 & 43.5 \\
\hline & & 15 & 24 & 96 & 1 & 4 & 20 & 87 & 3 & 13 \\
\hline & & 16 & 1 & 4 & 24 & 96 & 4 & 17.4 & 19 & 82.6 \\
\hline & \multirow{3}{*}{ İlişkilendirme } & 17 & 9 & 36 & 16 & 64 & 9 & 82.6 & 14 & 17.4 \\
\hline & & 18 & 9 & 36 & 16 & 64 & 2 & 8.7 & 21 & 91.3 \\
\hline & & 19 & 25 & 100 & 0 & 0 & 21 & 91.3 & 2 & 8.7 \\
\hline & \multirow[t]{2}{*}{ Tahmin Yürütme } & 20 & 25 & 100 & 0 & 0 & 21 & 91.3 & 2 & 8.7 \\
\hline & & 21 & 21 & 84 & 4 & 16 & 17 & 73.9 & 6 & 26.1 \\
\hline \multirow{10}{*}{ 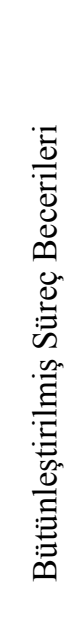 } & \multirow{3}{*}{ Değişkenleri Kontrol Etme } & 22 & 13 & 52 & 12 & 48 & 10 & 43.5 & 13 & 56.5 \\
\hline & & 23 & 5 & 20 & 20 & 80 & 8 & 34.8 & 15 & 65.2 \\
\hline & & 24 & 6 & 24 & 19 & 76 & 15 & 65.2 & 8 & 34.8 \\
\hline & \multirow[t]{3}{*}{ Verileri Yorumlama } & 25 & 25 & 100 & 0 & 0 & 19 & 82.6 & 4 & 17.4 \\
\hline & & 26 & 23 & 92 & 2 & 8 & 17 & 73.9 & 6 & 26.1 \\
\hline & & 27 & 23 & 92 & 2 & 8 & 13 & 56.5 & 10 & 43.5 \\
\hline & Hipotez Oluşturma & 28 & 5 & 20 & 20 & 80 & 12 & 52.2 & 11 & 47.8 \\
\hline & \multirow[t]{2}{*}{ Yaparak Yanttlama } & 29 & 2 & 8 & 23 & 92 & 2 & 8.7 & 21 & 91.3 \\
\hline & & 30 & 1 & 4 & 24 & 96 & 7 & 30.4 & 16 & 69.6 \\
\hline & Deney Yapma & 31 & 22 & 88 & 3 & 12 & 9 & 82.6 & 14 & 17.4 \\
\hline
\end{tabular}


Tablo 3 incelendiğinde deney grubunda bulunan öğrenciler 1. madde olan gözlem yapabilme becerisine en düşük doğru cevabı vermiştir. Kontrol grubunda ise en düşük doğru olarak cevaplanan madde ise deney grubunda olduğu gibi 1. madde olarak saptanmıştır. En az cevaplanan maddelerin yüzdelik olarak gruplar arasındaki duruma bakıldığında deney grubu öğrencileri 1. maddeye doğru cevap veremezken, kontrol grubu öğrencilerinden 1. maddeyi 1 öğrenci doğru olarak cevaplamıştır.

Gruplara göre en çok cevaplanan maddelere bakılırsa 2. , 10. ,19. , 20. ve 25. maddelere deney grubu öğrencilerinin tamamının doğru cevaplamasıyla en çok cevaplanan maddeler olmuştur. Bu maddelerin analizleri yapıldığında gözlem, sayıların kullanılması, tahminde bulunma, verileri yorumlama becerilerini kapsadığı tespit edilmiştir. Kontrol grubu öğrencileri ise 10.maddeye 22 öğrenci cevabı ile en çok doğru cevaplanan madde durumuna gelmiştir. Yüzdelik oranlarına bakıldığında ise öğrencilerin \%95.7'sinin 10.maddeye doğru cevap verdiği sonucuna ulaş1lmıştır. Öğrencilerin verdiği cevaplar doğrultusunda kontrol grubu öğrencilerinin doğru ortalamas1 \%62.1, deney grubu öğrencilerin doğru ortalamas1 ise \%61.6 olduğu görülmektedir. Kontrol grubu öğrencileri deney grubuna göre daha yüksek doğru ortalamasina sahiptir.

Uygulama öncesinde deney ve kontrol grubunun BSBT başarıları açısından anlamlı bir farklılık olup olmadığını belirlemek amacıyla t testi yapılmış, verilerin analizinden elde edilen bulgular Tablo 4'de sunulmuştur.

Tablo 4

Deney ve kontrol grubu ögrencilerin BSBT ön test skorları analiz bulguları

\begin{tabular}{lllllrc}
\hline & $\mathrm{N}$ & $\bar{X}$ & $\mathrm{~S}$ & $\mathrm{Sd}$ & $\mathrm{t}$ & $\mathrm{p}$ \\
Deney & 25 & 59.89 & 10.43 & 46 & 1.17 & 0.248 \\
Kontrol & 23 & 56.00 & 12.57 & & & \\
\hline
\end{tabular}

${ }^{*} \mathrm{p}>.05$ olduğunda fark anlamlı değildir. $\quad{ }^{*} \mathrm{p}<.05$ olduğunda fark anlamlıdır.

MTYBT deney ve kontrol grubu ön test puanlarının analiz bulguları Tablo 4'te $\mathrm{p}=0.248$ olduğu belirlenmiştir. Belirlenen değer 0.05 'den büyük olduğu için, gruplar arasındaki ilişkinin $\mathrm{p}>0.05$ düzeyinde istatistiksel olarak anlamlı olmadığı söylenebilir. Yapılan t-testi sonuçları ve gruplara ait ortamlalar birlikte değerlendirildiğinde, kontrol grubu öğrencilerinin BSBT' de deney grubu öğrencileri ile özdeş bir başarıya sahip olduğu denilebilir.

\section{İkinci Alt Probleme İlişkin Bulgular}

Bilimsel Süreç Becerileri Testi uygulandığında, deney ve kontrol gruplarının son-test puanları arasında anlamlı düzeyde bir farklılık var mıdır? şeklinde olup, ilgili testin son-test olarak uygulanmasindan elde edilen deney ve kontrol grubu öğrencilerinin doğru cevap yüzdeleri Tablo 5 'de sunulmuştur. 
Tablo 5

BSBT Son testine Kontrol ve Deney Grubu Öğrencilerinin Doğru Cevap Verme Oranlart

\begin{tabular}{|c|c|c|c|c|c|c|c|c|c|c|}
\hline & \multirow[t]{4}{*}{ Beceriler } & Madde & \multicolumn{4}{|c|}{ Deney Grubu } & \multicolumn{4}{|c|}{ Kontrol Grubu } \\
\hline & & \multirow[t]{2}{*}{ Numaras1 } & \multicolumn{2}{|c|}{ Doğru } & \multicolumn{2}{|c|}{ Yanlış } & \multicolumn{2}{|c|}{ Doğru } & \multicolumn{2}{|c|}{ Yanlış } \\
\hline & & & $f$ & $\%$ & $f$ & $\%$ & $f$ & $\%$ & $f$ & $\%$ \\
\hline & & 1 & 8 & 32 & 17 & 68 & 1 & 4.3 & 22 & 95.7 \\
\hline & \multirow[t]{3}{*}{ Gözlem Yapma } & & & & & & & & & \\
\hline & & 2 & 22 & 88 & 3 & 12 & 18 & 78.3 & 5 & 21.7 \\
\hline & & 3 & 13 & 52 & 12 & 48 & 12 & 52.2 & 11 & 47.8 \\
\hline & \multirow[t]{3}{*}{ Uzay Zaman İlişkisi } & 4 & 14 & 56 & 11 & 44 & 15 & 65.2 & 8 & 34.8 \\
\hline & & 5 & 16 & 64 & 9 & 36 & 14 & 60.9 & 9 & 39.1 \\
\hline & & 6 & 17 & 68 & 8 & 32 & 15 & 65.2 & 8 & 34.8 \\
\hline & \multirow[t]{4}{*}{ Sinıflandirma } & 7 & 17 & 68 & 8 & 32 & 16 & 69.6 & 7 & 30.4 \\
\hline & & 8 & 22 & 88 & 3 & 12 & 20 & 87 & 3 & 13 \\
\hline & & 9 & 21 & 84 & 4 & 16 & 19 & 82.6 & 4 & 17.4 \\
\hline & & 10 & 25 & 100 & 0 & 0 & 20 & 87 & 3 & 13 \\
\hline & \multirow{3}{*}{ Sayıları Kullanılma } & 11 & 17 & 68 & 8 & 32 & 16 & 69.6 & 7 & 30.4 \\
\hline & & 12 & 20 & 80 & 5 & 20 & 16 & 69.6 & 7 & 30.4 \\
\hline & & 13 & 9 & 36 & 16 & 64 & 7 & 30.4 & 16 & 69.6 \\
\hline & \multirow[t]{2}{*}{ Ölçüm Yapma } & 14 & 16 & 64 & 9 & 36 & 14 & 60.9 & 9 & 39.1 \\
\hline 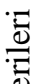 & & 15 & 24 & 96 & 1 & 4 & 16 & 69.6 & 7 & 30.4 \\
\hline D & \multirow{4}{*}{ İlişskilendirme } & 16 & 22 & 88 & 3 & 12 & 4 & 17.4 & 19 & 82.6 \\
\hline 坣: & & 17 & 13 & 52 & 12 & 48 & 12 & 52.2 & 11 & 47.8 \\
\hline $\bar{\Xi}$ & & 18 & 18 & 72 & 7 & 28 & 8 & 34.8 & 15 & 65.2 \\
\hline 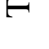 & & 19 & 23 & 92 & 2 & 8 & 18 & 78.3 & 5 & 21.7 \\
\hline & \multirow[t]{3}{*}{ Tahmin Yürütme } & 20 & 22 & 88 & 3 & 12 & 20 & 87 & 3 & 13 \\
\hline$\overline{\underline{\theta}}$ & & 21 & 17 & 68 & 8 & 32 & 17 & 73.9 & 6 & 26.1 \\
\hline 它 & & 22 & 14 & 56 & 11 & 44 & 16 & 69.6 & 7 & 30.4 \\
\hline 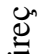 & \multirow{2}{*}{ Değişkenleri Kontrol Etme } & 23 & 17 & 56 & 8 & 32 & 14 & 60.9 & 9 & 39.1 \\
\hline 告 & & 24 & 12 & 48 & 13 & 52 & 12 & 52.2 & 11 & 47.8 \\
\hline$\underline{\Xi}$ & \multirow[t]{3}{*}{ Verileri Yorumlama } & 25 & 21 & 84 & 4 & 16 & 17 & 73.9 & 6 & 26.1 \\
\hline$\frac{\mathbb{d}}{=}$ & & 26 & 21 & 84 & 4 & 16 & 17 & 73.9 & 6 & 26.1 \\
\hline : & & 27 & 20 & 80 & 5 & 20 & 11 & 47.8 & 12 & 52.2 \\
\hline & Hipotez Oluşturma & 28 & 14 & 56 & 11 & 44 & 5 & 21.7 & 18 & 78.3 \\
\hline
\end{tabular}


Yaparak Yanitlama

Deney Yapma

Tablo 5 incelendiğinde deney grubunda bulunan öğrenciler gözlem becerisini ölçen 1. maddeye en düşük cevabı vermiştir. 1. maddeye deney grubu öğrencileri 8 doğru cevap verdiği görülmüştür. Kontrol grubunda ise en düşük doğru olarak cevaplanan madde ise deney grubunda olduğu gibi 1. madde olarak saptanmıştır. En az cevaplanan maddelerin yüzdelik olarak gruplar arasındaki durumuna bakıldığında deney grubu öğrencileri 1. maddeye \%32 doğru cevap verirken kontrol grubu öğrencileri 1. maddeye \%4.3 doğru cevap verdiği gözlenmiştir.

Gruplara göre en çok doğru cevaplanan maddelere bakılırsa 10. maddeye deney grubu öğrencilerinin tamamının doğru cevaplamasıyla en çok cevaplanan madde olmuştur. Bu doğru cevaplanan soruların yüzdelik oranlarına bakıldığında öğrencilerin maddelere \%100 oranla doğru cevap verdikleri görülmektedir. Kontrol grubu öğrencileri ise 8., 10. ve 20. maddelere 20 öğrenci doğru cevab1 ile en çok doğru cevaplanan madde durumuna gelmiştir. Yüzdelik oranlarına bakıldığında ise öğrencilerin \%87'sinin bu maddelere doğru cevap verdiği sonucuna ulaş1lmıştır. Öğrencilerin çoğunluğunun doğru cevapladığı maddelerin analizleri yapıldığında sınıflandırma, sayıların kullanılması, tahminde bulunma becerilerini kapsadığı tespit edilmiştir. Öğrencilerin verdiği cevaplar doğrultusunda kontrol grubu öğrencilerin doğru ortalamas $\% 57.1$, deney grubu öğrencilerin doğru ortalamas1 ise \%70.5 olduğu görülmektedir. Deney grubu öğrencileri kontrol grubuna göre daha yüksek doğru ortalamasina sahiptir.

Tablo 6

Deney ve kontrol grubu ögrencilerin BSBT son test skorları analiz bulguları

\begin{tabular}{ccccccc}
\hline & $N$ & $\bar{X}$ & $S$ & $S d$ & $t$ & $p$ \\
Deney & 25 & 65.81 & 10.43 & 46 & 2.87 & 0.006 \\
Kontrol & 23 & 55.86 & 13.50 & & & \\
\hline \multicolumn{2}{c}{$*$ p $>$.05 olduğunda fark anlaml değildir. } & $* \mathrm{p}<$.05 olduğunda fark anlamlıdır. &
\end{tabular}

BSBT deney ve kontrol grubu son test puanlarının analiz bulguları Tablo 6'da $\mathrm{p}=0.006$ olduğu belirlenmiştir. Belirlenen değer 0.05 'den küçük olduğu için, gruplar arasındaki ilişkinin $\mathrm{p}<0.05$ düzeyinde istatistiksel olarak anlamlı olduğu söylenebilir. Yapılan t-testi sonuçları ve gruplara ait ortamlalar birlikte değerlendirildiğinde, deney grubu öğrencilerinin BSBT' de kontrol grubu öğrencilerinden daha başarılı olduğu denilebilir. 


\section{Sonuç ve Tartışma}

Aşağıda araştırmaya katılan öğrencilerin deneysel çalışma öncesi ve sonrası uygulanan bilimsel süreç becerileri testinin istatistiksel analizi sonucu elde edilen bulgulara dayalı olarak oluşturulan sonuçlar özetlenmektedir.

Bilimsel Süreç Becerileri Ön Test Puanlarına İlişkin Sonuçlar: Yapılan deneysel çalışma öncesinde deney ve kontrol grubunda yer alan öğrencilerin bilimsel süreç becerileri arasında anlamlı düzeyde bir farklılık yoktur. Yani her iki grubun öğrencileri sahip oldukları bilimsel süreç becerileri bakımından denktirler.

Bilimsel Süreç Becerileri Son Test Puanlarına İlişkin Sonuçlar: Deneysel çalışma sonrasında araştırmaya katılan deney ve kontrol gruplarındaki öğrencilerin bilimsel süreç becerileri puanları arasında istatistiksel olarak anlamlı farklılık bulunmaktadır. 4E aşamalı öğrenme yaklaşımının kullanıldığı deney grubundaki öğrenciler araştırma süresince araştırmacı tarafından geliştirilen materyalin sahip olduğu bilimsel süreç becerilerini kullanmayı öğrenmişler ve bu becerilerini geliştirmişlerdir. 4E aşamalı öğrenme yaklaşımı, Milli Eğitim Bakanlığı tarafından okutulan, çağdaş yaklaşımlar ve sahip olduğu yöntemlere göre bilimsel süreç becerilerini geliştirmede daha etkili olmuştur.

Bilimsel süreç becerilerine yönelik hazırlanan etkinliklerle öğrenim gören deney grubu öğrencilerinin, bilimsel süreç becerileri testinden aldıkları puanların ortalaması, kontrol grubu örencilerinin puanlarının ortalamasından daha yüksek çıkmıştır. İstatistiksel olarak 0,05 düzeyinde anlamlı bulunan bu fark, deney grubu öğrencilerinin kontrol grubu öğrencilerine göre bilimsel süreç becerileri ve akademik başarı düzeylerinin daha fazla arttığını göstermektedir. Bununla birlikte, her iki grubun öntest- son-test puanları kendi içinde karşılaştırıldığında; her iki grubun da bilimsel süreç becerilerinin arttığı, dolayısıyla da her iki öğretimin (Bilimsel süreç becerilerine yönelik hazırlanan etkinliklerle ve programdaki öğretimin) de öğrencilerin bilimsel süreç becerilerinin gelişimine anlamlı bir katkı sağladığı görülmektedir (Basağa ve ark., 1994; Westbrook ve Rogers, 1994; Keller, 2001; Kanlı ve Yağbasan, 2008; Aydoğdu ve Ergin, 2009).

Çalışmada deney grubu öğrencilerinin, kontrol grubu öğrencilerine göre değişkenleri tanıma ve tanımlayabilme, hipotez kurma ve tanımlama, işlemsel açıklamalar getirebilme, problemin çözümü için gerekli incelemelerin tasarlanabilmesi verileri yorumlayabilme gibi bütünleştirilmiş bilimsel süreç becerilerine daha hakim olduğu söylenebilir. Bu durum deney grubu öğrencilerinin bilimsel süreç becerilerini kendilerinin yapılan etkinliklerle kazandıklarını gösterebilir. Etkinlikleri yaparken bu süreci bizzat yaşadıkları için bu beceriler ile bilimsel bilgiye kendileri ulaşmış olduklarından sözü edilen becerilerin gelişmiş olması gerçekten materyalin etkililiğinin bir göstergesi olabilir. Aynı şekilde literatürde de yapılan çalışmalarda (Arslan, 1995; Carey ve ark., 1989; Brickhouse ve ark., 2000; Shiibeci and Murcia, 2000; Roberts, 2001; Rivas, 2003; Can, 2007; Bağc1-Kılıç ve ark., 2007) bu görüşü destekleyici niteliktedir. 
Öğretimde birincil derecedeki kaynaklar, gerçek materyaller ve deneyimler kullanılması deney grubu öğrencilerinin başarısının artmasında büyük rol oynamıştır. Kavramların görselleştirilerek somutlaştırılması öğrencinin daha kalıcı ve anlaşılır şekilde anlamasına yardımcı olacağı bilinmektedir (Kara, Kahraman ve Baştürk, 2008; Köseoğlu ve Kavak, 2001; Harman, 2012). Bu görüş doğrultusunda etkinlikler ve konu kapsamında yer alan kavramlar somutlaştırılmış ve öğrencinin günlük yaşamında karşılaştığı problemler etrafında, yaşantılara yer verilerek daha etkili bir öğretim gerçekleştirilmek istenmiştir. Somut materyallere ve deneyimlere yer verilen etkinliklerle yürütülen derslerde öğrencilerin bilimsel süreç becerilerini daha iyi geliştirdiği çalışmalarla ortaya konmuştur (Nicosia ve ark., 1984; Glasson, 1989; Germann ve ark., 1996).

Öğrencilerle etkileşim içinde olabilecekleri etkinlikler ile öğrencilerin iletişim becerilerinin gelişmesi amaçlanmıştır. Etkileşimli öğretimin, öğrencinin anlamasını kolaylaştırdığ 1 yadsınamaz bir gerçektir. Bu etkinliklerle öğrenciler kendilerinden farklı olan öğrencileri kabullenme, birbirlerine saygı duyma, özgüven kazanma ve sorumluluk duygularının gelişmesi gibi birçok beceriyi geliştirdiği de bilinmektedir ( Akçay, Tüysüz ve Feyzioğlu, 2003; Karamustafaoğlu, 2006).

Deneyler ile yürütülen bir fen ve teknoloji dersi daha anlaşılır ve daha kalıcı olduğu bilinmektedir ( Kaptan, 1999; Köseoğlu ve Kavak,2001; Aktepe, 2009). Deney yapma birçok beceriyi içermektedir. Tahmin, gözlem yapma, hipotez kurma ve değişkenleri tanımlama-kontrol etme gibi birçok beceriyi geliştirdiği de bilinmektedir. Deney etkinliklerine yeterince yer verilmeyen bir fen öğretiminde öğrencilerin deney düzenleme ve uygulayabilmesinin istenilen düzeyde olmayacağı, bilimsel süreç becerileri kapsamında verileri toplama, tahmin, sonuç çıkarma gibi becerilerin yeterli düzeyde desteklenemeyeceği ifade edilmektedir (Park, 2005). Bu durum karşısında kendini geliştiremeyen, araştırmalara kapalı, eleştirel düşünme becerilerinden yoksun öğrencilerin ortaya çıkacağı unutulmamalıdır (Güneş, Çelikler ve Gökalp, 2009).

\section{Öneriler}

Bilimsel süreç becerileri öğretim ve günlük yaşam içerisinde önemli bir beceri olarak yer almıştır. Bu kadar önemli olan becerilerin öğretim kitapları içeriğinde, öğrencilerin deneyimleri ile bütünleştirilerek yer verilmesi gerekmektedir. Bu anlayış 2004 öğretim programı ile öneminin anlaşılması sonucu yer verilmesine rağmen istenilen düzeye ulaştığı söylenemez. Halen fen öğretiminin laboratuvarlardan uzak, öğretmen merkezli yöntemler ile işlenmesi bu anlayışın eksik yanlarının olduğunu ortaya koymaktadır (Nicosia ve ark., 1984; Glasson, 1989; Germann ve ark., 1996; Park, 2005; Güneş, Çelikler ve Gökalp, 2009). Bu eksikliklerin giderilmesi için çalışmalar yapılabilir ve eksikliğin nedenleri araştırılabilir. Bu bağlamda yapılabilecek çalışmalar ve öneriler aşağıdaki gibidir.

Programın uygulayıcıları olan öğretmenler ile ilgili çalışmalar yapılabilir ve görüşlerine yönelik olarak ihtiyaçların giderilmesi için çalışmalar gerçekleştirilmelidir. 
Öğrencilere, bilimsel süreç becerilerini kazandırmada ve geliştirmede etkili olan deney çalışmalarının ilkokul kademelerinde olmak üzere her kademe seviyesinde kullandırılması ve laboratuvarların gerek MEB gerekse de okul müdürlükleri tarafından düzenlenmesi ve faaliyete geçirilmesi için çalışmalar yapilmalidir.

Ders kitapları bütün bilimsel süreç becerilerini eşit düzeyde kapsayacak şekilde olmalı ve öğrencilerin eksik becerilerini tamamlama imkanı sunmalıdır. Bu şekilde öğretimin daha etkili olmasına ve becerilerin daha iyi kazanılmasına yardımcı olacaktır.

Programa yönelik olarak geliştirilen ders kitaplarının bütünleştirilmiş süreç becerilerini kapsayacak etkinliklere yer verilmeli, uygulayıcıları olan öğretmenler ile bir portal kurulup, öğretmenlerin kendine özgü geliştirdikleri etkinlikler bir havuz oluşturularak diğer öğretmenlerin faydalanması sağlanmalıdır. 


\section{Kaynakça}

Akçay, H., Tüysüz, C., ve Feyzioğlu, B. (2003). Bilgisayar destekli fen bilgisi öğretiminin öğrenci başarısına ve tutumuna etkisine bir örnek: mol kavramı ve avogadro sayis1. The Turkish Online Journal of Educational Technology, 2(2), 5766.

Aktamış, H. (2009). İlköğretim düzeyinde bilimsel süreç becerilerini kazandırma yöntemlerinin örneklerle incelenmesi. İlköğretmen Ĕ̈itimci Dergisi, 30, 52-56.

Aktepe, V., ve Aktepe, L. (2009). Fen ve teknoloji öğretiminde kullanılan öğretim yöntemlerine ilişkin öğrenci görüşleri: Kırşehir BİLSEM örneği. Ahi Evran Üniversitesi Kırşehir Eğitim Fakültesi Dergisi, 10(1), 69-80.

Anagün, Ş. S. (2011). PISA 2006 Sonuçlarına göre öğretme-öğrenme süreci değişkenlerinin öğrencilerin fen okuryazarlıklarına etkisi. Eğitim ve Bilim, 36(162), 84-102

Arena, P.(1996). The role of relevance in the acquisition of science process skills. Australian Science Teachers, 42(4).

Arslan, A. (1995). Illkokul öğrencilerinde gözlenen bilimsel beceriler (Yayımlanmamış Doktora Tezi). Hacettepe Üniversitesi Sosyal Bilimler Enst. Ankara.

Ayas, A., Çepni, S. ve Akdeniz, A. R. (1993). Development of the Turkish secondary science curriculum. Science Education, 77(4), 433-440.

Aydoğdu, B. ve Ergin, Ö. (2009). Fen ve teknoloji dersinde kullanılan farkl deney tekniklerinin ögrencilerin bilimsel süreç becerilerine etkileri. Dokuz Eylül Üniversitesi, İzmir.

Bağc1-Kılıç, G., Metin, D., Yardımc1, E. ve Berkyürek, İ. (2007). Doğada bilim eğitimi. Illköğretim Kongresi: Illkögretimde Ĕgitim ve Öğretim Bildiri Kitabı (s:65-67). Hacettepe Üniversitesi. Kasım 2007 Ankara.

Basağa, H., Geban, Ö. ve Tekkaya, C. (1994). The effect of the inquiry teaching method on biochemistry and science process skill achievements. Biochemical Education, 22(1) 29-32.

Birinci, E. (2008). Materyal tasarımı ve geliştirilmesinde proje tabanlı öğrenmenin kullanılmasının öğretmen adaylarının eleştirel düşünme. Yaratıcı düşünme ve bilimsel süreç becerilerine etkisi (Yayınlanmamış yüksek lisans tezi). Zonguldak Karaelmas Üniversitesi, Zonguldak.

Büyüköztürk, Ş. (2001). Deneysel desenler: Öntest-sontest kontrol grubu desen ve veri analizi. Ankara: Pegem A Yayıncilık.

Büyüktaşkapu, S., Çeliköz, N., ve Akman, B. (2012). Yapılandırmacı bilim öğretim programının 6 yaş çocuklarının bilimsel süreç becerilerine etkisi. Ĕ̆gitim ve Bilim, 37(165), 274-291.

Brickhouse, N. W., Dagher, Z.R., Letts, W. J. ve Shipman, H. L. (2000). Diversity of students'views about evidence, theory, and the interface between science and 
religion in an astronomy course. Journal of Research in Science Teaching, 37(4) 340-362.

Can, B. (2007). Fen eğitimi ve yaratıc1lık. İlköğretmen Dergisi, 13, 42-45. Kasım 2007.

Carey, S. ve Evans, R. (1989). An experiment is when you try it and see if it works: a study of grade 7 students' understanding of the construction of scientific knowledge. International Journal of Science Education, 11, 514-529.

Çetin, O. ve Günay, Y. (2011). Fen eğitimine yönelik örnek bir web tabanlı öğretim materyalinin hazırlanması ve bu materyalin öğretmen öğrenci görüşleri doğrultusunda değerlendirilmesi. Ahi Evran Üniversitesi Eğitim Fakültesi Dergisi, 12(2).

Enger, S. K. ve Yager, R. E. (1998). The Iowa assessment handbook. The Iowa- SS\&C Project, Science Education Center, The University of Iowa, Iowa City.

Ergin, Ö., Şahin-Pekmez, E. ve Öngel-Erdal, S., (2005). Kuramdan uygulamaya deney yoluyla fen ögrretimi (1. Bask1). İzmir: Dinazor Kitabevi, Birinci Bask1, Kanyılmaz Matbaas1.

Germann, P. J., Haskins S. ve Auls, S. (1996). Analysis of nine high school biology laboratory manuals: promoting scientific inquiry. Journal of Research in Science Teaching, 33(5), 475-499.

Glasson, E.G. (1989). The effects of hands-on and teacher demonstration laboratory methods on science achievement in relation to reasoning ability and prior knowledge. Journal of Research in Science Teaching, 26(2), 121-132.

Goh, N. K., Toh, K. A. ve Chia, L. S. (1989). Use of modified laboratory instruction for improving science process skills acquisition. Journal of Chemical Education, 66 (5), 430- 432.

Güneş, M. H., Çeliker, D. ve Gökalp, M. (2009). İlköğretim II. kademedeki yeni fen ve teknoloji ders kitaplanı konusunda sınıf öğretmenlerinin görüşleri. Ç.Ü. Sosyal Bilimler Enstitüsü Dergisi, 17(3), 193-210.

Kanlı, U. ve Yağbasan, R. (2008). 7E modeli merkezli laboratuvar yaklaşımının öğrencilerin bilimsel süreç becerilerini geliştirmedeki yeterliliği. Gazi Eğitim Fakültesi Dergisi, 28(1), 91-125.

Kaptan, F. (1999). Fen bilgisi ögrretimi. İstanbul: Milli Eğitim Basımevi.

Kaptan, F., Korkmaz, H. (2000). Yapısalcılık (Constructivism) kuramı ve fen öğretimi. Çăgdaş Ĕ̈itim, Mayıs, 265, 22-27.

Karamustafaoğlu, O. (2006). Fen ve teknoloji öğretmenlerinin öğretim materyallerini kullanma düzeyleri: Amasya ili örneği. Atatürk Üniversitesi Bayburt Ĕ̆itim Fakültesi Dergisi, 1(1), 90-101.

Karamustafaoğlu, S. ve Kandaz, U. (2006). Okul öncesi eğitimde fen etkinliklerinde kullanılan öğretim yöntemleri ve karşılaşılan güçlükler. Gazi Eğitim Fakültesi Dergisi, 26(1), 65-81. 
Karamustafaoğlu, O. ve Sontay, G. (2012). Bir TIMSS sınavının ardından: TIMMS 2011'e katılan öğrenci ve uygulayıcı öğretmenlerin görüşleri, X. Ulusal Fen Bilimleri ve Matematik Ĕ̈itim Kongresi, Niğde.

Keller, T.J (2001). From theory to practice creating an inquiry-based science classroom (Yayınlanmamış Doktora Tezi). University of Pasific Lutheran.

Köseoğlu, F., ve Kavak, N. (2001). Fen öğretiminde yapılandırıcı yaklaşım

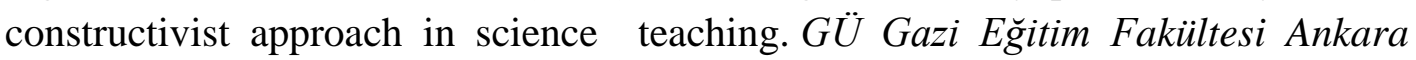
Dergisi, 21(1), 139-148.

Martin, R., Sexton, C. ve Gerlovich, J. (2002). Teaching science for all children: Methods for constructing understanding. Boston, USA: Allyn And Bacon.

Nicosia, M.L. Aiello, S., Mineo, R.M. ve Valenza, M.A. (1984). The relationship between science process abilities of teachers and science achievement of students: an experimental study. Journal of Research in Science Teaching, 21(8), 853-858

Ostlund, K. L. (1992). Science process skills: Assessing hands-on student performance. New York: Addison-Wesley.

Park, D. (2005). Differences between a standards-based curriculum and traditional textbooks in high school earth science. Journal of Geoscience Education, 53(5), 540-547.

Rivas, M.G.(2003). The nature of science and preservice elementary teacher: change in understanding and practice (Basılmamış Doktora Tezi). University of California.

Roberts, R. (2001). Procedural understanding in biology: the thinking behind the doing. The Journal of Biological Education, 35(3),113.

Sarıer, Y. (2010). Ortaöğretime giriş sınavları (OKS-SBS) ve PISA sonuçları 1şığında eğitimde firsat eşitliğinin değerlendirilmesi. Kırşehir Ahi Evran Üniversitesi Ĕgitim Fakültesi Dergisi, 11(3), 107-129.

Shiibeci, R.A. ve Murcia, K. (2000). Science is about fact or is it? Journal of College Science Teaching, 29(3), 205-209.

Şahin-Pekmez, E. (2000). Procedural understanding: Teachers' perceptions of conceptual basis of practical work (Yayınlanmamış Doktora Tezi). University Of Durham.

Taşar, M.F, Temiz, B.K. ve Tan, M. (2001). İlköğretim fen öğretim programında hedeflenen öğrenci kazanımlarının bilimsel süreç becerilerine göre sınıflandırılması $<$ www.Gazi.Edu.Tr/ Mftasar/Publications >(25.01.2006).

Turgut, M. F., Baker, D., Cunningham, R., ve Piburn, M. (1997). Illkögretim fen ögrretimi. Yök/ Dünya Bankası Milli Eğitimi Geliştirme Projesi Hizmet Öncesi Öğretmen Eğitimi: ANKARA

Westbrook, L. Susan ve Laura, N. Rogers (1994). Examining the development of scientific reasoning in ninth-grade physical science students. Journal of Research in Science Teaching, 31(1), 65-76. 